The possibilities of a beach: queerness and François Ozon's beaches

\title{
FIONA HANDYSIDE
}

The assertion that François Ozon's films are part of ‘a new queer cinema' has become a commonplace of academic writing about the director. ${ }^{i}$ Equally, recent criticism of the films has been unable to ignore the insistence with which they return to a beach setting, to the extent that the Guardian's film critic, Peter Bradshaw, labelled it his 'signature location', conferring the beachscape the role of auteurist sign in Ozon's filmography. ${ }^{\text {ii }}$ Of his eleven feature films released since 1998's Sitcom, four have heavily featured the beach (Sous le sable/Under the Sand [2001] 5x2; [2005]; Le Temps qui reste/Time to Leave [2006]; Le Refuge/The Hideaway [2009]). Furthermore, two of his shorts (one of which is rather more medium length, with a running time of an hour) also make use of the beach as a key site for the playing out of their stories (Une robe d'été/A Summer Dress [1996]; Regarde la mer/See The Sea [1997]). Not unsurprisingly, critics have traced links between Ozon's portrayal of a variety of sexual preferences and practices and his predilection for the beachscape. Both Andrew Asibong and Kate Ince interpret his beaches as a queer site at which the attractive ambiguity of the shoreline, neither land nor sea but a play between the two, figures as a metaphor for the shifting desire and identities of his protagonists. Asibong summarizes the ocean as an 'unstoppable location of otherness', a place where Ozon's bourgeois characters, through their contact with wild nature, find themselves confronted with an enormity they cannot control. ${ }^{\text {iii }}$ Ince argues that the beach is a 
transformative space which enables Ozon's characters to construct new relational modes, a term she borrows from Leo Bersani and Ulysse Dutoit's reading of Pedro Almodóvar's Todo sobre mi madre/All About My Mother (1999) (a film which, although it does not directly reference a beach location, exploits the mise-en-scene of a shift from the capital centre of Spain, Madrid, to the coastal and peripheral Barcelona as key to this process). ${ }^{\text {iv }}$ Similarly, Thibaut Schilt sees the site of the beach as part of Ozon's attraction for the 'foreign', considering it as a metaphor for 'elsewhere'.

Ozon's predilection for the ocean, and the beach that it so ceaselessly laps, clearly has a metaphorical function as a site of liquidity, fluidity and change. However, while Ozon's characters often enjoy non-normative sexual encounters on or near beaches, these are a result, not a cause, of its queer identity. His films offer a way of envisaging a queer cinema that is not predicated on individual bodies performing discrete acts but which aims to create a framework for constantly reconfiguring what queer forms and practices might be. We can move beyond 'queer' as a focus on sexual identities towards a more rigorous challenge to the corralling of bodies into (hetero and homo) normative scripts. Lee Edelman and Judith Halberstam argue that a queer temporality is one that rejects the telos of the social order. If, for homophobic societies, alternative sexualities are tragic because they fall outside of 'the natural order', Edelman and Halberstam insist on demonstrating the constructed and oppressive nature of that order, proclaiming a power in rejecting its very terms and rebelling against the privileging of maturity and 'the future'. This essay identifies the beach as a queer site not because of the sexual encounters that take place there but because it is a location where the body's relationship to time and space is (consistently) reconfigured. Although Edelman's forceful assertion that queerness 
must react 'against the cult of the Child and the political order it enforces [to say] that we do not intend a new politics, a better society, a brighter tomorrow' has understandably caused great controversy and a concomitant interest in the possibilities of a queer utopian project, his rejection of the future as a fantasy that shores up normative social arrangements has great heuristic value for a reading of Ozon's beachscapes and their queer potential. ${ }^{\text {vi }}$ Ozon's characters sometimes appear as figures looking towards a beautiful sun setting beyond the horizon, but this shimmering image of 'a brighter tomorrow' is relentlessly undercut by trauma and demise: murder in Regarde la mer; disappearance in Sous le sable; death in Le temps qui reste; rape in $5 \times 2$.

Elizabeth Grosz argues that attention to space is key to rethinking the body. 'If bodies are to be reconceived, not only must their matter and form be rethought, but so too must their environment and spatio-temporal location. ${ }^{\text {vii }}$ She reminds us that space and time are never experienced as mathematical or geometrical abstractions but in and through our bodies. ${ }^{\text {viii }}$ The beach is a site where the body is on display. Turning to an interview conducted with Ozon on his website, he notes the ambiguity and primacy of the body on the beach. 'Lying on the beach myself, I've often pondered all the bodies lying around me. "What if somebody here doesn't get up? What if he isn't sleeping, or getting a tan, what if he's dead?" ,ix The beach is a different kind of spatio-temporal location and allows for the reconfiguration of the body compared to other sites. It is the place where corporeality and the sensations of the body come to the fore. In an extended consideration of the way the beach and the body interact, Jennifer Webb argues that the beach

resonates in memory [as] expanses of sand and moving water, hot sun and nearly naked adult bodies, days of endless play and being buffeted by 
waves. ... It was a place distinct from everyday life because the beach seemed ... to be committed to, or at least permit, a kind of animal being, a democracy of the flesh where anyone could participate in play. ${ }^{\mathrm{x}}$

Alongside these readings of the beach as site of ludic bodily pleasures, Webb also discusses the fact that beaches are 'dangerous exquisite empty expanses which will not sustain human life' and that 'pleasure in the freedom of the sea contrasts to the assault on my body - sunburnt, sandpapered, thirsty, headachy, a body reminding me across every centimetre of its needs'. Ozon's films focus on our embodied experiences of the beach, forcing us into close physical proximity with sand and water AS FOR FN. 10? (Yes -FH) through long-duration closeups or sequence shots when he films beaches. He thus emphasizes both the pleasures and the threats for bodies on the beach, so that the coherence of the body itself finally comes undone.

Ozon's films demonstrate time and again the ambiguity of the body on the beach, not (just) in relation to desire and pleasure but towards temporality itself. Are bodies alive or dead? Are these images of people or ghosts? Are they from the past, the present, or the future? All these questions can prove difficult to answer with regard to Ozon's beaches. As Ozon explains later in the same interview, beaches operate as a recurrent symbol because, 'beaches are timeless spaces, they provide abstraction and purity' ${ }^{\mathrm{xi}}$ In their timelessness, beaches become queer sites, undoing heteronormativity's insistence on a linear march towards the future and queering affective relations by insisting on the coexistence of differing experiences of time.

In this essay I will offer close readings of the beachscapes in $5 \times 2$, Sous le sable, Regarde la mer and Le Refuge in order to illustrate the different ways in which Ozon uses this location to disturb normative linear configurations of time and its harnessing to a procreative future. My decision to concentrate on these four films 
rather than his other beach-set films - Une robe d'été, which narrates a joyful sexual encounter between a young gay man and an older Spanish woman at the beach, and Le Temps qui reste, in which a gay photographer chooses to go to a beach in Brittany for his final hours before his death from cancer - is a polemical one. Each of these films features an ostensibly straight woman (Sasha in Regarde la mer; Marie in Sous le sable; Marion in $5 \times 2$; Mousse in Le Refuge) rather than a gay man as its main character and may therefore seem tangential to Ozon's queer cinematic project. At this point we should bear in mind Harry Benshoff and Sean Griffin's argument that 'queer can be used to describe any sexuality not defined as heterosexual procreative monogamy (usually the presumed goal of most classic Hollywood couplings); queers are people (including heterosexuals) who do not organise their rhetoric according to this rubric' ${ }^{\text {xii }}$ Benshoff and Griffin importantly remind us that the category of queer extends beyond same-sex orientation; extending this assertion, paying attention to queer temporality 'shifts our attention away from discrete bodies performing their desires [and] offers an alternative framework for the theorisation of disqualified ... queer practices' ${ }^{\text {xiii }}$

Although Edelman's reading of the social as inoperable for the always already shattered queer subject takes place through a psychoanalytic optic, his description of the self 'as a mere prosthesis maintaining the future for the figural Child' has a much broader sociocultural resonance. In his response critiquing Edelman and positing a queer politics of futurity, José Munoz nevertheless acknowledges 'the ever-increasing sidewalk obstacles produced by over-sized baby strollers on parade in the city in which I live, the sheer magnitude of the vehicles that flaunt the incredible mandate of reproduction as world-historical virtue'. ${ }^{\text {xiv }}$ Munoz's mention of the outsize baby stroller alerts us to the material structures that support what Diane Negra refers to as 
'hypermaternity', both a rationale for motherhood and a form of conspicuous consumption that celebrates it as the redemptive and enriching necessity of (economically comfortable) women's lives. ${ }^{\mathrm{xv}}$ Edelman's critique becomes particularly pertinent with regard to the female lifecycle promoted within postfeminist culture, which posits pregnancy as a state of transcendent femininity. If, for Edelman, the self is encouraged to be 'the agent of reproductive futurism', this is surely even more so for women, in keeping with the notion discussed by Negra that motherhood is understood as conferring authentic self-knowledge amidst a dizzying array of potential identity categories. Ozon's female characters are able to reject this sentimental positioning of motherhood. In his films the impact of reproductive futurism on women's bodies is demonstrated, and revealed to be not a privileged moment of subjectivity but rather a cause of trauma, abjection and disavowal. Ozon's queer temporality disrupts the traditional heterosexual romance trajectory for these straight women and shifts from a consideration of bodies and their individual desires and actions to an alternative framework of kinship that rejects the normative force of futurity.

Judith Halberstam defines queer time as 'a perverse turn away from the coherent narrative of adolescence - early adulthood - reproduction - child-rearing retirement - death'. As such, queer time challenges both hetero and homo normativities, functioning as a 'critique of the careful social scripts that usher even the most queer among us through major markers of individual development and into normativity'. ${ }^{\text {xvi }}$ Ozon's characters turn away from these scripts, both literally in the case of $5 \times 2$ 's reversed chronology, and metaphorically through an engagement with ghosts, phantoms and doubles. Notably, this spectrality is often associated with the figure of the Child. When Romain in Le Temps qui reste visualizes his childhood self 
looking back at him in the bathroom mirror, it is not the first time that the viewer has seen him. The very first frame of the film, as the opening credits come up, is of a boy on a beach looking out to sea; we see the back of his head with its dark curls, and Melvil Poupard's name appears to its left. This opening image is paradigmatic, confusing past and present, virtual and actual. The actor playing the child Romain is actually Ugo Soussan Trabelsi, but the name projected alongside his head is that of the actor playing his adult self. The image is irrelevant to the story, serving simply to introduce us to the beach and its confusion of the identities and histories via a spectral image of a child that is impossible to locate correctly in time (the adult Melvil Poupard both is and is not the young boy whose image accompanies his name) and that acts within the filmic diegesis as a harbinger of death. In the film's final sequence, which takes place on a Breton beach, the adult Romain encounters his childhood self. Although he has encountered this image at various moments throughout the film, firstly as a reflection in a bathroom mirror, then in the evening woods, then playing a prank in a church, it is not until we reach the beach that the two actually interact with each other. As Romain sits alone on the beach, the widescreen frame picking out his gaunt, pale body in sickly contrast to the tanned bodies around him, a child's blue beach ball flies into the frame. Romain picks up the ball and passes it back to the child, and they smile at each other in shot/reverse-shot. The image is utterly ambiguous, bringing together two different sets of time and creating an overlapping circuit of the past and the present until any difference between the two is indecipherable. The film's storyline, of a young gay man dying of cancer who agrees to a woman's request to father a child for her and her infertile husband, has attracted vitriol from some quarters and could indeed be read as the most conservative favouring of the unborn child over the dying, gay father. ${ }^{\text {xvii }}$ This sequence, however, makes it impossible to 
read the film in such limiting terms. The final image we see of the child is not a sentimental emblem of the future but a spectre, a haunting from the past, and the queer figure is himself reconfigured and doubled by the child rather than simply relegated beyond the frame. Far from privileging the vertical, patriarchal view of time as linear reproduction, this image fuses different time periods into overlapping circuits, an image of horizontality that echoes the expanse of the beach.

Ozon's films in general overcome the association of childhood with the future through spectrality. ${ }^{\text {xiii }}$ This leads to a queer configuration that fuses different times rather than the sentimental image of the child shoring up reproductive futurity, as discussed by Lee Edelman. For example, Siofra in Regarde la mer functions as the embodiment of Tatiana's aborted/stillborn child, and Mousse's pregnancy in Le Refuge sustains her in its connection to her dead lover, looking to the past rather than with any interest to the future baby (who she leaves to her lover's brother). These proliferating ghosts allow a queering within the normative frameworks of reproductivity, and in doing so transform them. Through the figure of the spectral child, characters experience desire out-of-time, with affective pulls associated with the ghostly child coming from the past and history, rather than being firmly located in the future.

For Edelman queer time overwhelms time's march to the future. In heteronormative futurism there is 'the faith that temporal duration will result in the realisation of a meaning by way of a "final signifier" that will make meaning whole at last'. ${ }^{\text {xix }}$ In contrast, Edelman rebels against such a concept of time and 'generational succession, temporality, and narrative sequence' ${ }^{x x}$ Ozon's beaches also rebel against normative succession, defying the way in which films are frequently structured towards such a definitive goal and endpoint, a 'final signifier'. If we look across the 
range of Ozon's beach films, the beach location is often placed at the beginning or the end of the film, or at both beginning and end. This structure favours circularity and repetition over linearity and goal-oriented narrative: Regarde la mer, for example, starts with a black screen and the sound of lapping waves; Le Temps qui reste finishes in exactly the same way. In both films the beach is the site of abjection and death, disrupting temporal relations between past, present and future. In Regarde la mer Tatiana finishes the film by stealing Sasha's child, probably as a replacement for her own dead baby. The mother and daughter image we see in the film's final frame is a complex fusion of past and future relations between Sasha, Tatiana and their offspring, Tatiana having transformed her appearance in order to appear similar to the now dead Sasha. Other Ozon films also finish at the beach on a note of striking ambiguity concerning temporal organization. Sous le sable finishes with Marie running along a desolate Atlantic beach towards a shadowy figure, a harbinger of her romantic future, perhaps, but who also may connote the husband who drowned there the summer before, a figure from her past. $5 \times 2$ offers us a stunning final image of a Sardinian beach at sunset, as Marion and Gilles run into the sea together. This is a declaration of desire that is undercut by our knowledge of the relationship's demise, ending in anal rape post-divorce in a chilly Parisian hotel room. The reverse chronology of the film makes the beach stand for both the beginning (of Marion and Gilles's relationship) and the end (of the film). In all these films the beach operates within many layers of temporality, being simultaneously a container of the past, the present and the future. As such it speaks to Edelman's desire to undo linearity and halt futurity, placing us instead into a space of meaningless circulation and repetition of the drive (rather as the constant lapping of waves may suggest repetitive circularity).

Ozon's films use various devices to deviate from the picture-postcard image of 
the beach. He favours the beaches of the west (Brittany) or southwest (the Landes) of France rather than the Mediterranean resorts more readily associated with glamour and wealth, such as St Tropez. This interest in representing the French southwest relates his work to other queer artists such as the bande dessinée artist Fabrice Neaud, the director André Téchiné and the screenwriter, actor and director Jacques Nolot (who is cast by Ozon in Sous le sable), all of whom showcase the location as somewhere with 'permeable borders (whether geographic, political or social) [which] undo oppositions and engender a reformulation of eroticism'. The southwest provides a topography of desire that is 'a border zone, a crossroads, a hybrid mix of traditions and experiences placed between the mountainous Pyrenees and the wooded hills of the back country, where the curving roads lead eventually to the Atlantic Ocean' ${ }^{\text {xi }}$ Ozon's beaches are usually fairly wild and remote, not the more groomed beaches of the holiday resort. We see characters who are bored or distracted, trying but failing to read their books rather than contentedly absorbed. Lastly, of course, as discussed above, beaches often represent a threat to his characters, who drown in the ocean or expire on the sands. The beach in $5 \times 2$, then, is rather unusual in its conventional beauty, and the chief protagonists Marion and Gilles are a rather conventional couple, certainly for Ozon. We see them fall in love, marry and have a child, fulfilling the prescribed heteronormative romance narrative. This narrative, however, is related to us in reverse order, and this temporal rearrangement alters both the idyllic beach location and the romance narrative it begins. Any idea of an idealized relation between his central couple is cruelty undercut by starting the film with Marion's brutal rape, just as the beautiful image of the beach in $5 \times 2$ as a site of plenitude and the promise of the fulfilment of sexual desire is undercut by our knowledge of the violence and grief that will follow (furthermore, as Schilt points out, we can have a 
more cynical view of Marion and Gilles's meeting on the beach even within that selfcontained sequence, as Gilles is actually on holiday with his girlfriend Valérie and is therefore about to commit adultery $)^{\text {xxii }}$.

Given the reverse chronology of the film, we witness the sexual violence of Marion's rape before we see her initial meeting with Gilles, thus their fate is experienced as inevitable. Indeed, thanks to this chronology, the beach has a complex double construction in the film in terms of temporality. In chronological terms the beach location is at the start, propelling Marion and Gilles forward into their story as a couple. The idyllic sunset and rather unrealistic emptiness (given that this is located in a busy holiday resort) speak to the image of the beach as paradise, a haven from the city and a place for the uncomplicated expression of love, desire and sexual pleasure. In terms of story order, however, the beach is found at the end of the film as the site of cruel irony and deceptive lures. The beach functions simultaneously as both beginning and end, depending on whether we are reading for the plot-order or the story-order, echoing the way it is both end and beginning for Gilles and Marion within the narrative (the end of his relationship with Valérie, the start of his relationship with Marion; the end of Marion's life as single woman, the start of her life as part of a heterosexual couple). As Ince discusses, this (con)fusion of the beach's temporal status is further enhanced on the DVD release of the film, as the viewer can choose to view a reedited version of the film where the scenes play in chronological order, entitled $2 \times 5$. The beach is perhaps not so much either 'past' or 'future' as it is both beginning and end, idyllic and threatening. In this way, we can absolutely see the beach of $5 \times 2$ as 'queer', although the coupling that occurs here is between a man and a woman and matches their respective claimed sexual orientations. It is queer, then, not because of the gender and sexual tastes of Ozon's protagonists but because it 
overcomes binary oppositions (h[e]aven vs hell, past vs future) in favour not so much of fluidity between identity categories as the permeability, to the point of erasure, of the boundaries between them.

Ozon's beach in $5 \times 2$ queers time through simultaneity, functioning as both past and future, beginning and end. It offers a shimmering vision of hope and futurity undercut by a violent undertow of danger, a reflection of the dual nature of the sea. This rethinking of spatiotemporal location causes the self to be reconfigured, as subjectivity itself is founded on the positioning of the body in space and time. The body is queered, but not through an exclusive focus on sexuality. Rather than functioning as an envelope for a goal-oriented subject in a manner favoured by classical cinema, Ozon's beach bodies are subject to a multiplicity of experiences which occur simultaneously. none of which can be reduced to heterosexual reproductive futurity. Sexual experiences which we may consider 'queer', such as oral sex performed by a (presumably gay) man cruising in woods near a beach, are open to ostensibly 'straight' characters, such as a young mother, as occurs in Regarde la mer. The body is shown basking in sunshine, protected by suntan cream (the very last action Marie's husband in Sous le sable will perform for her is applying suntan lotion to her back), but also as horribly vulnerable: to the water, to disease, to death (the body recovered from the sea in Sous le sable, genetically identified as that of Jean, is so disfigured by the water that it can no longer be visually identified). It is through the figure of Jean that the ambiguity of the beachly body reaches its apogee in Sous le sable.

Sous le sable finishes with an image of its central protagonist, Marie Drillon, running away from the camera along the shoreline of a wild Atlantic beach near Litet-Mixe in the Landes region of France. Importantly she is running towards the figure 
of a man: a nondescript, small figure, too far away from the camera for us to decipher. For years Marie and her husband Jean had visited the area, owning a holiday home there. The summer before this final dramatic flight from the camera, however, Jean had disappeared on this beach, presumably drowned. Following the harrowing search for a body, in which the soundtrack is dominated by the threatening combination of whirring helicopter propellers and crashing surf, drowning out the conversation Marie has with the lifeguards, the film returns abruptly to Paris. The transition occurs nineteen minutes into the film, via a shot of the dark waters of the Seine at nighttime, the camera then tilting up to an apartment where a dinner party is taking place. We then remain in Paris with Marie, the beach location being thoroughly repressed; any further shots of water are even more tame than those of the Seine compared to the ocean - the flat, sterile waters of the swimming pool at the gym where Marie regularly exercises. Tellingly it is Portishead's Denied that plays on the soundtrack over the transitional image of the inky Seine, linking this substitution/repression of the beach and the events that occurred there to a more general concept of denial and delusion. For the majority of the film Marie will stubbornly cling to a belief/hope that her husband has not disappeared, and he remains a bulky physical presence (whether a ghost, a demented hallucination or a fantasy is uncertain) in her Parisian flat. She still buys him presents, makes him breakfast, and refers to him in the present tense when chatting about him with her friends. However, following a dramatic confrontation with her mother-in-law, who asserts that Jean is still alive and, far from drowning, chose to leave the barren Marie who was unable to provide him with a family, she returns from Paris to the Landes in order to identify his body at the morgue. The scene that follows underlines the way in which Jean's subjectivity has been utterly removed by the actions of the sea, as the police pathologist describes in clinical detail the rotten, 
putrescent state of the corpse which remains resolutely offscreen, unable to be made image. Jean no longer functions as either a perspective or an object in space. In being 'lost at sea' he loses his identity and his subjectivity. The separation between his body and his environment has been negated as his lungs have filled with seawater, so that the differences between interior and exterior, body and sea, have broken down. Following the 'official' identification of Jean's body at the morgue - where Marie finally asserts that this body cannot be that of her husband, refusing to recognize its watch, much to the consternation of the officials and flying in the face of genetic and dental evidence - Marie returns to the original site of her trauma, grief and loss, the beach.

Consisting of nine shots in total, this sequence lasts approximately four minutes, giving an average shot-length of thirty seconds - three times the duration of an average mainstream Hollywood shot). Relatively long takes have been employed before in the film by Ozon: the arrival of Jean and Marie at their holiday home in the Landes takes six shots at the start of the film, each lasting an average of twenty-five seconds. Ozon's use of the long take works alongside a muted palette of greys, browns and blues to make his film seem more 'realistic' (that is to say, more within the aesthetic codes of European art-house cinema and its investment in neo-Bazinian realism) than his brash and flamboyantly camp Sitcom (1998) or 8 Femmes (2002). Certainly the use of long shots in this sequence combines with the location shooting to give a documentary feel to the depiction of this autumnal beach. Ozon records the physical reality of the location, combining long shots facing the sea with long shots looking down the beach at right angles to the sea. We see the crashing waves and a large piece of driftwood to the left of the screen, emphasizing the emptiness and expanse of the beachscape. In contrast to these long shots, he also uses a series of 
closeups on Marie's hands and face. The third shot of the sequence, and the first closeup, shows us Marie's right hand, still wearing her wedding ring. It paws and digs at the sand, literalizing the film's title for us and alerting us to the close physical connection bodies can have with beaches, literally covering themselves in the matter of the beach. It recalls, perhaps, in a minor key the fate of Jean's body, where the environment of the beach and the human body become interlaced with each other so that it is impossible to tell where one finishes and the other begins (of course the hand holding particles of matter such as dust or sand is often invoked as an image of human mortality). On the soundtrack we hear her heavy breathing and whimpers over the omnipresent crashing waves. We cut from her hand working the sand to a closeup on her face. This shot lasts for one minute and ten seconds, and brings us brutally into contact with Marie's grief. Ozon's combination of long take and closeup draws attention to the physicality of Marie's bodily presence and the depth of her grief and distress as she places her head in her hands and sobs. Throughout the film Marie has been attentive to displaying her body as conventionally physically attractive: attending the gym, applying anti-ageing creams to the skin beneath her eyes, buying a figure-hugging red dress. Now she abandons herself to grief and the viewer is forced to bear witness to her suffering. This shot was partially inspired by the conclusion of Ming-liang Tsai's Taiwanese film Vive l'amour (1994), in which we see the heroine cry for a total of six minutes and twenty-five seconds. As Schilt comments, 'in contrast to Tsai's work, which finishes on that note after a simple fade out, this is not the end of Ozon's film' xxiii The film then cuts to a shot of Marie in profile, and she turns to face the camera. She looks beyond the camera, alerting the viewer to something she has seen offscreen. She stands up and it cuts again, to a long shot down the beach. We see what has caught Marie's attention: the figure of a man standing by 
the waves, looking out to sea. Soft piano music starts to play on the soundtrack and Marie runs away from the camera towards the figure. The camera stays still, so that as Marie runs away she becomes increasingly small and insignificant. We have moved from the intensity of her bodily presence in the closeups on her hand and face to a renewed insistence on the immensity of the beach, nearly absent of human presence. The shot lasts for forty-five seconds, recording Marie's running without a break, the ever-increasing number of footprints she leaves behind in the sand testifying to the duration of the shot. The credits roll before Marie reaches the (real or imagined) man. This final image sets up a series of questions for the viewer concerning the function of the beach in Sous le sable and speaks to the conflictual forces of the beachscape more generally in Ozon's films. The question in Sous le sable rests on how we choose to identify the male figure that Marie runs towards, and whether we correspondingly see the beach as a space of delusion and psychosis or of healing. Ginette Vincendeau comes down firmly on the side of madness in her reading of the film. She argues that Marie is demented, a typical incarnation of the misogyny of French national cinema that 'loves beautiful, tragic women who go crazy'. The fact that 'these women are portrayed by expert directors ... and embodied by such talented actresses ... makes the fantasy more attractive, but also more bitter'. xxiv Vincendeau is rather harsh on both the character of Marie and the film itself, ignoring the way that both are coming to terms with a major traumatic event. Furthermore, she neatly maps Marie's character onto the beach, claiming that 'Marie looks increasingly like the beach in the film: beautiful but vacant'. Again this seems a rather severe judgement, and of course the ambiguity of the beach (and whether we should judge Marie as insane) rests precisely on the fact that the beach is not entirely vacant. Certainly this is not the crowded beach full of holidaymakers favoured by Eric Rohmer in Pauline à la 
plage/Pauline At the Beach (1982) or Le Rayon vert/The Green Ray (1986); indeed, Jean and Marie deliberately make the decision to visit a less busy beach, yet it is emphatically not deserted. In the opening sequence Marie questions a naked couple about whether or not they have seen her husband, their nudity recalling an idyllic view of the couple - Adam and Eve before the fall - and underlining the depth of Marie's loss. More importantly, of course, the enigma of the final sequence rests on the identification of the shadowy man standing by the waves. The man is extremely far from the camera so it is difficult to tell anything about him with certainty. His ambiguity profoundly affects how we read the end of the film: is this figure another ghostly hallucination of Jean, born of desperation to deny his death? Or is this figure a different man who attracts Marie precisely because he is not Jean, but rather offers hope of a new relationship? The film plays precisely on the notion that although the beach, and indeed Marie, may appear to be vacant, they are in fact both haunted by Jean. The figure of the ghost itself further troubles the distinction between absence and presence, vacancy and plenitude; ghosts are simultaneously both there and not there. This neatly maps onto the ambiguity of the beachscape itself, which depends on the ever-changing combination of absence and presence, of water and land, for its identity.

The question of Marie's madness is posed for us by the actions of the beach: it is, after all, the beach that causes Jean's sudden disappearance, and the beach is where Marie finishes the film running towards a male figure - the site, perhaps, not just of absence and loss but of futurity and hope, though notably not a futurity based on the sentimental image of the Child. Her wracking sobs - this is the first time we have seen her cry - could suggest that the beach has potential to be the place where Marie finally accepts that her husband is indeed dead and begins another stage in the long 
process of mourning his loss. In this reading, far from being demented, Marie's reaction to both beach events is entirely sane. She is utterly traumatized by the initial disappearance of her husband, but on her second visit to the beach she begins to come to terms with the reality of her loss and to imagine a new relationship beyond it.

However, as my discussion has made clear, the male figure on the beach is determinedly undecipherable. We return again to the doubled nature of the Ozonian beach, as Marie is offered it both as a site of possible new connections (pleasures), or continuing trauma and loss (vulnerabilities). The male figure could well stand for all or any of these things, her lost husband, her potential future lovers, or indeed indicating an utter indifference to her plight - although it appears that Marie is running towards the figure, their trajectories are slightly misaligned so we cannot be sure she will actually come into contact with him. He is a figure marked as queer, radically undermining temporal categories (he is a figure from the past, the present and the future) and ontological states (he is a physical presence, a psychotic hallucination and a libidinal fantasy). As the difference between past, present and future becomes untenable, so the beach becomes propitious to haunting.

Ozon's haunted beaches speak to us about the nature of cinema itself, and suggest that a potential queer temporality exists within the cinematic apparatus. Colin Davis summarizes the ghost as 'that which is neither present nor absent, neither dead nor alive'. ${ }^{\mathrm{xx}}$ As such, the ghost and the cinematic image have an ontological similarity, but they also share other qualities. In her reading of Jacques Derrida's Spectographies, Emma Wilson argues that Derrida aligns spectrality and mourning with moving image representations, showing that in both the subject is deprived of touch: 'what we are deprived of, in spectrality as when we look at images, the cinema, or the television, is tactile sensibility'. ${ }^{\text {xxi }}$ As she digs her hand into the sand, Marie 
desperately tries to reestablish physical contact with her dead husband, as if the beach where he disappeared may retain some aspect of his corporeality. With its closeup on the varying textures of sand and skin the image has a haptic quality, bringing the film spectator closer to the embodied experience of the beach. However, as Derrida's quote reminds us, neither ghosts nor cinematic images actually allow for physical contact. Through suggesting the closeness of the cinematic image of a man and his ghost in this final sequence - we cannot tell if we are looking at a ghost or not - Ozon demonstrates the uncanny queer potential at the heart of cinema. With its ability to fragment time and space, usually denied through the mechanisms of continuity editing and plot-driven narratives that also favour (implicitly heteronomative) goals, progress and futurity, cinema can showcase the (potentially queer) haunting, doublings and repetitions that the beachscape privileges through its geographical and cultural location as site of waves and wind, erosion, erasure and obscure marginality.

The most radical of Ozon's films in their undoing of heterosexual reproductive futurity through the figure of the spectral child on the beach are Regarde la mer and Le Refuge, as both films suggest modes of maternity that can operate outside of normative frameworks. Their very titles draw links between maternity and the beach, the former through a play on the well-known homonym of mer and mère, the latter through an evocation of the similarity in discourse of the womb and the beach as a haven from the world, This association is played upon in the French publicity poster for the film, which features an image of Isabelle Carré cradling her pregnant belly while stood at the edge of crashing waves. Furthermore, the return to the theme of the maternity and the beach in Le Refuge, some twelve years after the release of Regarde la mer, signals a fascinating response to broader issues of queerness and temporality more generally within Ozon's filmography. 
Ozon's films have provoked controversy within French critical tradition over the vexed question of whether or not he can be considered an auteur, given their generic and stylistic hybridity. His constant switching between different styles, from close intimate studies of grief to high camp musicals and melodramas, has made him an awkward figure for a relatively conservative critical tradition. His decision to return to the beach for Sous le sable was greeted by Patrice Blouin in the pages of Cahiers du cinéma in the following fulsome terms:

with Sous le sable, François Ozon has returned to the beach. One of his first shorts, La Robe d'été, and his mid-length Regarde la mer, which allowed him to establish a precocious reputation, had already been set at the edge of the Atlantic. After two rather disappointing features ... the director has finally returned to the site of his first love. ${ }^{\text {xxvii }}$

For Blouin, the return to the beach signals at last the delivery of the promising feature film long awaited from the precocious Ozon. Yet Ozon did not stay at the beach, choosing to return in his next film, 8 Femmes (2002), to the location of his 'failures', the melodramatic, garish, camp family home. Ozon has continued to oscillate between high camp and subtle chamber pieces, the former usually set in enclosed family homes, the latter often using a beach. Furthermore, the family home and its melodramatic tendencies has often led to relative commercial failure: for example the distinctly kitsch period drama Angel (2007) was not released on DVD in the USA. Angel also attracted a certain level of critical opprobrium, with Asibong labeling it 'an utterly alienating cinematic experience'. ${ }^{\text {xxviii }}$ By returning in 2009 to the beach, and by picking up the themes of pregnancy and its effects on the woman's body last explored in 1997, Ozon defies auteurist expectations of continuous development within a director's filmography, constructing a body of work that is circular, nomadic, and 
takes different trajectories. Rather than allowing critics to posit an 'early' or a 'late' Ozonian filmic persona, he removes himself from attempts to corral his films into such a normalizing narrative. ${ }^{\text {xix }}$

The figure of the future child, the key emblem of heterosexual reproductive futurity, finds its full force in Le Refuge. Just ten minutes into the film, Mousse wakes up in hospital and is told by a doctor that her lover Louis has died from an overdose of heroin and that she is pregnant. Mousse decides to keep the baby, against the wishes of Louis's bourgeois mother who explicitly requests that she abort the child as 'the family does not wish for Louis to have any descendents, now that he is no longer with us'. She leaves Paris for the 'refuge' of the title, a house by the sea in the extreme southwest of France. However, this child is not experienced by Mousse as an emblem of the future, but as a spectral presence from the past: as Ozon explains:

Le Refuge doesn't speak about the relationship with the child, because we virtually don't see the child. What interested me was the pregnancy: the gestation period. ... What is interesting is that Isabelle Carré's character in this film considers that the child doesn't exist. She has something in her stomach, but it is more of an extension of the man she loved than a full-fledged person. ${ }^{\mathrm{xxx}}$

There is an intense scene on the beach in which a middle-aged woman attempts to force Mousse into a relationship with her child. The woman is played by Marie Rivière, a casting decision that creates several layers of intertextual meaning: in Le temps qui reste Rivière was Romain/Melvil Poupard's mother; in Le Refuge Poupard plays Louis, the father of Mousse's child, so we can read Rivière as a grandmother figure to Mousse's child through casting. ${ }^{\text {xxi }}$ As the two women paddle in the sea together, Ozon's camera circles around them, showing the dramatic coastline of 
engulfing waves and large concrete blocks planted on the beach. Rivière falls to her knees and caresses Mousse's pregnant belly, telling her that she must accept suffering and give everything to her child, even if later in life the child is ungrateful. Mousse utterly rejects this discourse of maternal suffering and sacrifice, leaving Rivière impotently screaming her message to the waves as she walks away. As Mousse walks away, the graffiti on the concrete blocks is revealed, and alongside the spray painted images is an official warning that reads ACCES INTERDIT: DANGER, reiterating Mousse's desire to avoid attempts to penetrate her belly and give meaning to the foetus within it as new life. Later, Mousse will be approached by a middle-aged man at a cafe who wants to have sexual intercourse with her as he is turned on by pregnant women as long as he is not the father of the child (he tells Mousse he was unable to have sex with his wife while she was pregnant). Mousse accompanies him to his holiday apartment, but is unable to have sex with him. She asks him to simply cradle her, and he sits behind her and rocks her. The camera tracks down their bodies to rest in closeup on four hands caressing Mousse's stomach, and then tracks back up to show Mousse falling back against his shoulder in an attitude of abandon that recalls the scenes of her taking heroin with Louis. The conventional image of the pregnant woman's stomach as site of plenitude and futurity is complicated here: the image of hands on her stomach is a displacement of sexual intercourse that is specifically and precisely not about reproduction but non-normative sexual gratification, and Mousse asserts her needs over those of both her putative future child and the stranger.

Mousse articulates the terrible, gendered vulnerability that she feels as a pregnant woman. When Paul, Louis's gay younger brother who is staying with her, and Mousse have to go to the basement to mend the gas connection, she tells him that she would be afraid to go alone because it is in these locations that strange things 
happen. Rather as if she has seen Regarde la mer and learnt from Sasha's naivety, when she hears strange noises at night she grabs a large kitchen knife before she goes to investigate. It is simply Paul returning late at night from a nightclub, either high or drunk. The film does not shift into a register of horror, but these intimations of fear suggest that Mousse could be as vulnerable as Sasha when the traveller Tatiana turns up at her door.

Initially, at least, Regarde la mer sets up Sasha and Tatiana as polar opposites. Sasha and her daughter Siofra are often dressed in or surrounded by bright, primary colours while Tatiana is dressed in black or dark green. Sasha and Siofra are often seen in outdoor spaces - the beach and the garden - while Tatiana goes to supermarkets and cemeteries, the neon lighting and isolation respectively underlining their eeriness. Tatiana is constantly associated with dirt: when she bathes, it is in murky white water, and in a heavily commented upon scene, she goes to the toilet and then dips Sasha's toothbrush in her own unflushed faeces. Sasha later thoroughly brushes her white teeth with the sullied toothbrush, contrasting her careful dental hygiene with Tatiana's malicious actions. Sasha, the mother, is thus associated with cleanliness, light and life, and Tatiana with dirt, darkness and death. As Alice Stanley comments, '[Tatiana and Sasha] and the peculiar friendship they strike up underpin ... polar opposites ... such as cooked/uncooked, clean/unclean, life/death' xxxii Thierry Jousse's review of the film in Cahiers du cinéma was entitled 'Sans toit ni loi', reinforcing the link to Agnès Varda's 1985 film of the same name (released as Vagabond in the UK) and the similarities between Tatiana and Varda's Mona, another young female hitchhiker who embraces 'freedom and dirt'. xxxiii $Y e t$, if we can see a counter-cinema feminist lineage between Tatiana and Mona, the film also offers a more sympathetic portrayal of the young mother Sasha than either condemning or 
idealizing her decision to conform to cleanliness and maternity. In the film's opening sequence, the sound of Siofra's cries dominate the soundtrack and we see Sasha's difficulties in tending to her child. She is bored, tired and lonely, left alone by her husband who rarely calls her, partly because of cultural assumptions that the mother should be the prime carer for the child. Sasha is deprived of sexual and intellectual stimulation. Her desperation to reach out to Tatiana, despite the latter's obvious lack of interest, suggests that her vulnerability may at least partly result from patriarchal culture's veneration of the maternal role while failing to recognise the incredible sacrifice of personal, intellectual and sexual energy it demands of the woman. Patriarchal culture's simultaneous veneration and repression of mothers and babies, pushing them to the margins, is literalized in the image of Sasha and Siofra together on the beach, watched over by the hawk-like Tatiana with 'her backpack cemented to her like a dead baby, seen by the attentive Siofra but not the oblivious Sasha' ${ }^{\text {xxiv }}$ The first image we see of Tatiana in the film is a low-angle shot of her watching the mother and daughter on the beach from a cliff-top, a shot that recalls and references an image of Elisabeth looking at the sea from a cliff-top in Ingmar Bergman's Persona (1966). Regarde la mer has many similarities to Bergman's film: both tell the story of two women spending time by the beach; both show the women gradually merging identities; both use excessive shot/reverse-shot technique to film a long coercive dialogue between two women concerning maternity. Through referencing such a classic of European arthouse cinema, Ozon reminds us of the importance of the beachscape in this cinematic tradition for thorough investigations of sexual and gender politics, in the films of Antonioni (such as L'Avventura [1960], a possible intertext for Sous le sable with their stories of disappearance and prominent use of water), Fellini and Truffaut, as well as Bergman. 
The beach location echoes the peripheral space allocated to the mother and daughter in the husband's mind as he continues working in Paris. In this film, maternity opens one up to endless vulnerability - Tatiana brutally questions Sasha about the physical process of birth, asking if her vagina tore and if she needed an episiotomy - a discussion that foreshadows her stitching up of Sasha's vagina after she has murdered her. Beyond this critique, the beach becomes a radically uncertain border space in terms of the status of the child who, as she takes her first uncertain steps on the sand, straddles the border between infancy and childhood, crawling and walking. She does not exist here as an uncomplicated vision of the future and hope, but acts as a reminder to Tatiana of an unspoken trauma concerning her own child, who never attained such independence. This trauma is located in the way that pregnancy causes the dissolution of all boundaries, any sentimental expression at the thought of the mother and baby bond this implies overridden by the horror of defilement and the mixing of faeces, blood and urine evoked in Tatiana's discussion of childbirth with Sasha. Tatiana both reveres and is repulsed by Sasha, recalling Freud's list of those categories which are considered taboo in certain societies, including men at their initiation ceremonies, women during menstruation, women after childbirth, newborn babies, the sick, the dead, and a man's personal possessions. ${ }^{\mathrm{xxv}}$ Sasha is taboo in her own right as she has recently given birth and is still breastfeeding. Grosz argues that 'the body becomes a human body, a body that coincides with the shape and space of a psyche, a body that defines the limits of experience and subjectivity only through the intervention of the (m)other and, ultimately, the Other (the language and rule-governed social order)' ${ }^{\text {xxxvi }}$ If the mother is key to the production of the body, Regarde la mer traumatically interrupts this process by revealing the mother's body as abject and taboo. Rather than maternity 
leading to the affirmation of Tatiana's subjectivity, as a heteronormative, postfeminist culture may wish to claim, here motherhood is shown to undermine the mother's subjectivity and to render her body vulnerable because abject.

In contrast, Mousse and Paul overcome these binary oppositions that characterize abjection. It is Mousse who wears dark glasses and clothes and who bathes in opaque, grimy water, and Paul who wears casual clothes, often brightly coloured (such as his red shorts) and visits the beach. Gradually Mousse and Paul become close, and the binary oppositions of light and dark, beach and cemetery, become undone - they visit both together. Eventually, Mousse rejects the role of motherhood that Marie Rivière attempts to impose on her in the liminal beach space (she also refuses to visit a church and pay homage to the Virgin Mary). The film's final scene shows her leaving the hospital grounds alone on the Metro. As the camera moves into closeup on Mousse's face, her voiceover explains that she has decided to bequeath Louise, her baby daughter, to Paul. Recalling the queer paternity offered by Le temps qui reste, in which Romain fathers a child for an infertile couple, the film offers up an image of alternative kinship that is not based on heteronormative reproduction and its investment in the sacrifice of the mother's body but rather through opening up the family to new connections and becoming a more expansive network of individuals. In both Regarde la mer and Le Refuge, the liminality of the beachscape works to challenge the idealization of motherhood and reproductive futurity through an articulation of the taboo and abject aspects of motherhood and its simultaneous veneration and marginalization. The figure of the Child on the disturbed temporal site of the beach becomes ghostly and virtual, evoking the past and the draw of death as much as any drive to the future. In Regarde la mer, Sasha is engulfed by these forces, and Tatiana steals her identity and her baby. In Le Refuge, however, 
Mousse uses this insight to reject the heteronormative positioning of her pregnancy.

Such a rejection of the sentimental framing of motherhood is key to rethinking relations between children and adults and combating homophobic notions of the family, as Judith Butler demonstrates. In an era she describes as

a time in which the family is at once idealized in nostalgic ways within various cultural forms, the Vatican protests against homosexuality not only as an assault on the family but also on the notion of the human, where to become human, for some, requires participation in the family in its normative sense. ${ }^{\text {xxxvii }}$

Butler points out the way that family relations have changed and concludes that this is an era 'in which kinship has become fragile, porous and expansive'. xxxviii

These adjectives are obviously well suited to the beachscape, with the friability of its sand, its seepage of water into land, and its endless horizontality all emphasized in Ozon's film through long shots over beaches combined with closeups of body parts covered in sand. The beach could thus be argued to capture metaphorically the shifting nature of kinship outlined by Butler. However, Ozon's beaches offer a far more radical vision than an attractive metaphorization. The beachscape operates in a different temporal pattern to the city, acting as a marginal location of drives, repetition and circularity. In this environment, time changes its operation and, rather than being placed in service of a future predicated on reproduction, becomes doubled, operating as both past and future, beginning and end. Through this reconfiguration of time, the body itself is reconfigured. The body produced at the beach is not inscribed and coded into (family ordered) sexual desires which corral it into a normative narrative of development, but is caught between different affective states that emphasize the lure of the past and the uncanny. 
Elizabeth Grosz argues that bodies and cities exist in a mutually defining relationship, as the city is 'one of the crucial factors in the social production of (sexed) corporeality ... the city provides the order and organisation that automatically links otherwise unrelated bodies: it is the milieu in which corporeality is socially, sexually and discursively produced' xxxix Ozon's films demonstrate that the beach too can operate as a frame and context for the body, a body that is produced in different and non-normative ways. Oscillating between being a place of pleasure and freedom or being a place of pain, dissolution and death, with these differing states imbricated in its very figuration (the beach constantly shifts in its appearance through the action of wind and waves), the beach reimag(in)es corporeality. Ozon's beaches express his queer cinematic project as they contest notions of progress, rationality, linearity and the association of reproduction and kinship with these tropes in favour of temporal (con)fusion, affective relations from different time frames, and spectral encounters. As his characters chase phantoms across beaches, they act out and expose desire as operating beyond the bonds of time-limited heteronormative futurity, dissipating reactionary fantasies of the normative family and encountering an otherness that will not be tamed but that must be reckoned with.

\footnotetext{
${ }^{\mathrm{i}}$ See, for example, Andrew Asibong, François Ozon (Manchester: Manchester University Press: 2008); Michelle Chilcoat, 'Queering the family in François Ozon's Sitcom', in Robin Griffiths (ed.), Queer Cinema in Europe (Bristol: Intellect, 2005), pp. 23-33; Kate Ince, 'François Ozon's cinema of desire', in Kate Ince (ed.), Five Directors: Authorship From Assayas to Ozon (Manchester: Manchester University Press, 2008), pp. 112-34; Mark Pegrum, 'Virgins, vixens, vamps and victims: François Ozon's 8 Femmes and the sexual (sub)texts of French popular culture',
} 
Australian Journal of French Studies, vol. 42, no. 1 (2005), pp. 76-93; Nick Rees-

Roberts, French Queer Cinema (Edinburgh: Edinburgh University Press, 2008);

Thibaut Schilt, François Ozon (Urbana, IL: University of Illinois Press, 2011).

ii Peter Bradshaw, 'Time to leave', The Guardian, 12 May 2006, p. 18

${ }^{\text {iii }}$ Asibong, François Ozon, p. 142

iv Ince, 'François Ozon's cinema of desire', pp. 116-8.

${ }^{\vee}$ Schilt, François Ozon, p. 164

${ }^{\mathrm{vi}}$ Lee Edelman, No Future: Queer Theory and the Death Drive (Durham, NC: Duke University Press, 2004), pp. 30-31.

${ }^{v i i}$ Elizabeth Grosz, Space, Time and Perversion (London: Routledge, 1995), p. 84.

viii Grosz, Space, Time and Perversion, pp. 80-85.

${ }^{\text {ix }}$ François Ozon, 'Interviews about Time to Leave', <http://www.francoisozon.com/en/interviews-time-to-leave> accessed 10 April 2011.

${ }^{\mathrm{x}}$ Jennifer Webb, 'Beaches, bodies, and being in the world', in Keith Gilbert, James Skinner and Allan Edwards (eds), Some Like it Hot: the Beach as Cultural Dimension (Oxford: Meyer and Meyer Sport, 2003), p. 74.

${ }^{x i}$ Ozon, 'Interviews about Time to Leave'.

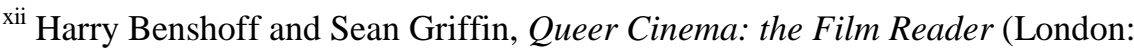
Routledge, 2004), p. 1.

xiii Judith Halberstam, quoted in Carolyn Dinshaw, Lee Edelman, Roderick A. Ferguson, Carla Freccero et al., 'Theorising queer temporalities: a roundtable discussion', GLQ: a Journal of Lesbian and Gay Studies, vol. 13, nos 2/3 (2007), pp.177-95.

xiv José Munoz, 'Cruising the toilet: LeRoi Jones/Amiri Baraka, radical black traditions, and queer futurity', GLQ: a Journal of Lesbian and Gay Studies, vol. 13, 
$\operatorname{nos} 2 / 3$ (2007), p. 355

${ }^{\mathrm{xv}}$ Diane Negra, What a Girl Wants? Fantasizing the Reclamation of the Self in Postfeminism (London: Routledge, 2009), p. 70.

xvi Judith Halberstam, quoted in Dinshaw et al., 'Theorising queer temporalities', p. 186.

${ }^{\text {xvii }}$ For a particularly vitriolic reading, see Polo, “"Every sperm is sacred”: Le temps qui reste ou le portrait réac d'un pédé petit bourgeois', Melanine, 25 January 2006; English-language version <http://www.melanine.org/article.php3?id_article=144> accessed 9 October 2011.

xviii Asibong has commented on the way that 'Ozon's world is brimming over ... with ghostly entities', but his interest is in the possibility (or not) of characters 'penetrating the spectre to reveal the monstrous mess lying beneath'. So far there has been no critical discussion of the complex links the films make between beaches, childhood, and haunting, and how this may align to a queer cinematic project. See Asibong, 'Spectres of substance: François Ozon and the aesthetics of embodied haunting', in Katie Griffiths and David Evans (eds), Haunting Presences: Ghosts in French Literature, Theory, Film and Photography (Cardiff: University of Wales Press, 2009), pp. 116-30.

${ }^{\text {xix }}$ Edelman, No Future, p. 37

${ }^{\mathrm{xx}}$ Ibid., p. 17.

${ }^{\text {xxi }}$ Philippe C Dubois, 'Révélations intimes: vers une cartographie queer du sud-ouest', French Literature Series: Queer Sexualities in French and Francophone Literature and Film, Vol. XXXIV (2007), pp. 163-75.

${ }^{\text {xxii }}$ Schilt, François Ozon, p. 133.

xxiii Ibid., p. 92. 
${ }^{\text {xxiv }}$ Ginette Vincendeau, 'Under the sand', Sight and Sound, vol. 11, no. 4 (2001) <http://www.bfi.org.uk/sightandsound/review/2138/> accessed 10 April 2011. ${ }^{x x v}$ Colin Davis, 'Hauntology, spectres and phantoms', French Studies, vol. 59, no. 3 (2005), p. 373.

${ }^{\text {xxvi }}$ Emma Wilson, 'Museum spaces in palliative art: Mariana Otero's Histoire d'un secret', L'Esprit Créateur, vol. 51, no. 1 (2011), p. 115.

xxvii Patrice Blouin, 'La Place du mort', Cahiers du cinéma, no. 554 (2001), p. 76. xxviii Asibong, François Ozon, p. 164.

${ }^{x x i x}$ Both Asibong and Schilt attempt to read Ozon's filmography in terms of development and maturity. Asibong argues that Ozon's films have become increasingly pessimistic and nihilistic, arguing that they have moved from genuinely radical transformation to 'a present quagmire of cynicism and solitude'; conversely, Schilt sees a 'drastic evolution' in Ozon's increasingly sympathetic portrayal of fatherhood. See Asibong, 'Spectres of substance', p. 129, and Schilt, François Ozon, p. 153.

${ }^{\mathrm{xxx}}$ Schilt, François Ozon, p. 158

${ }^{\text {xxxi }}$ Rivière is best known for her work with Eric Rohmer (who also cast Melvil Poupard), including the beach-set The Green Ray/Le Rayon vert (1986). There she plays Delphine, a woman who is searching both for a partner and the green ray that will confirm her choice. She ends the film by the beach at St Jean de Luz, seated next to a man she met at the train station in Biarritz and crying with joy as she spots the green ray which seems to confirm she has indeed found happiness. Her appearance in Le Refuge on this beach, so geographically close to St Jean de Luz, suggests that this may be an aged Delphine. Her cries that one must suffer in childbirth and love children even if they turn out to ungrateful suggest, however, that the heteronormative 
relation she was so keen to construct has been difficult and painful rather than the idyllic solution she imagined.

xxxii Alice Stanley, 'Representations of sexuality in the films of François Ozon' (Unpublished PhD thesis, University of Warwick, 2010), p. 24.

xxxiii Thierry Jousse, 'Sans Toit ni loi’, Cahiers du cinéma, no. 519 (1997), pp. 66-67. The expression 'freedom and dirt' is taken from Chris Darke, 'Vagabond: freedom and dirt', 21 January $2008<$ http://www.criterion.com/current/posts/501-vagabondfreedom-and-dirt> accessed 23 April 2011. Asibong also notes the connections between Regarde la mer and Sans toit ni loi, commenting that Ozon grants far more agency to his homeless female drifter 'albeit of a psychotic nature' than Varda does hers. Asibong, François Ozon, p. 54.

${ }^{\text {xxxiv }}$ Ibid., p. 57.

${ }^{\mathrm{xxxv}}$ Sigmund Freud, The Origins of Religion: Totem and Taboo, Moses and Monotheism and Other Works (London: Penguin, 1990), pp. 76-77.

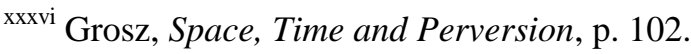

xxxvii Judith Butler, Antigone's Claim: Kinship Between Life and Death (New York NY: Columbia University Press, 2000), p. 22.

xxxviii Butler, Antigone's Claim, p. 23.

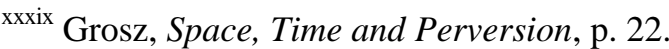

